\title{
'Between You and Her No Comparison': Witches, Healers, and Elizabeth I in John Lyly's Endymion
}

In the late 1580s, John Lyly was pursuing his aspiration to be made the master of the revels at the court of Elizabeth I. As part of this ambitious project, he presented the queen with the play Endymion, the epilogue of which explicitly sets out the playwright's hopes of preferment, urging her highness to 'vouchsafe with [her] favourable beams to glance upon' the performance (Epilogue, 13-14). ${ }^{1}$ While Lyly chose a classical — and thus distant - tale of Endymion's love for the Moon as the basis for his play, ${ }^{2}$ he also strove to secure the interest of his prospective audience by engaging thoroughly with contemporary concerns - in particular, with the current debate on the subject of witchcraft. To enter the debate, Lyly introduces the witch Dipsas, a character not found in any of the versions of the classical myth: she is appropriately malevolent, disruptive of the natural order, and ultimately inferior to Cynthia, the Moon and the healer who rehabilitates the order upset by the witch and represents Queen Elizabeth herself. The two characters may be easily imagined as occupying the opposite ends of the spectrum and engaging in a battle of powers where the weaker one is vanquished and the stronger triumphs. This juxtaposition, however, is complicated by closer analysis of the two figures and their relationship: as Philippa Berry points out, 'Lyly's use of witchcraft as a central element in his plot should have reminded anyone versed in classical mythography of the connections between Cynthia or Diana and witchcraft'. ${ }^{3}$ As both Berry and Christine Neufeld argue, Cynthia's maids - and specifically Tellus — act to destabilize the suggested dichotomy by acting as 'the channel between the exceptional Cynthia and the discourse of monstrosity that taints the rest of femininity', ${ }^{4}$ and 'these misogynistic representations also contaminate by their proximity the icon of Elizabeth'.5

And yet, while Berry and Neufeld brilliantly highlight the connection between the flawless Moon and the wicked witch and bring to the fore- 
ground the importance of other women in the play, they do not take into consideration the thrust of the contemporary witchcraft debate, which seeks not to expose and overthrow the powerful witch but to elide her completely. To a large degree, as Stuart Clark shows, such elision was typical of protestant demonology, which strove to move away from the layperson's emphasis on the figure of the witch and the act of maleficium. ${ }^{6}$ While pre-reformation works, such as Malleus Maleficarum, focused on the powerful and malevolent female witch and the disasters that she wreaked, protestant writers were much more interested in the victim's perception of harm and reaction to it. In 1584, shortly before the estimated date of Endymion's composition, Reginald Scot condemned those who believed in the supernatural abilities of witches, writing that 'he that attributeth to a witch, such divine power, as dulie and onelie apperteineth unto GOD ... is in hart a blasphemer, an idolater, and full of grosse impietie. ${ }^{7}$

Such a shift in emphasis also reflected on the figure of the female healer, which was already becoming suspect before the reformation and merging with the figure of the witch. Malleus Maleficarum spoke with indignation of 'those affected by sorcery [who] run to superstitious womenfolk, by whom they are very often freed and not by priests or exorcists' and the cases where 'acts of sorcery are broken with the help of demons. ${ }^{8}$ In the protestant learned discourse, folk healers - most commonly imagined as women ${ }^{9}$ - were evil only insofar as they enabled the mistaken and blasphemous belief in maleficium and in miraculous cure from it, which they were incapable of performing. In other words, treatise writers suggested that witches and healers were guilty of the same offence - claiming power and difference where none existed - but in reality did not differ from other women, shrewish and loquacious as they might have been.

Clearly familiar with this line of argument, Lyly must have also been aware of its lack of influence on the popular culture: accusations and trials continued, and cunning-folk were still consulted in the cases of bewitchment. In Endymion, written explicitly for the benefit of the court in general and for Elizabeth in particular, the playwright engages closely with these questions and attempts to resolve them, offering an argument similar to that of protestant theologians but uniquely constructed along the lines of his position as a courtier. Like the treatise writers, Lyly ultimately argues against the existence of powerful witches; unlike them, he allows for the existence of a highly powerful woman healer. The presence of this figure, however, is not at all meant to authorize healing practices for the rest of women: idealized to 
such an extent that there is no question of emulation, Cynthia rises far above all other women in the play. This unequal competition with the Moon's authoritative and authorized power renders Dipsas impotent and laughable, her magic abilities insignificant and ineffectual.

As Berry and Neufeld have argued, Lyly destabilizes the dichotomy between Cynthia and Dipsas, but rather than serving to call forth the monstrous potential in all women, Dipsas is revealed to be no more powerful and fear-invoking than the rest of the female characters. The witch disappears, merging with the rest of womankind and closing this potential avenue to the female audience. The healer remains but, far from opening the sphere of benevolent magic and healing to all women, Endymion is at pains to show the true singularity of Cynthia's power, to which she has access precisely on the basis of her uniqueness and exalted status. As Berry has suggested, Lyly emphasizes Cynthia's position in relation to other women in the play; however, his main focus is not 'upon the space which the female monarch shared with other women', ${ }^{10}$ but on the impassable gap that separates their respective spaces. Cynthia's status as the Moon literally places her above the world of humans, in a position from which she can observe others and regulate their behaviour. Remaining the only unmarried major female character by the end of the play, Cynthia actively polices other women and forces them out of the public sphere; the very existence of this character works to define and circumscribe the area of female activity.

Effectively, through participating in the current debate concerning witches and healers, the play seeks to address the problem of a woman ruler and is preoccupied with the implications of the existence of a powerful woman who does not intend to marry. ${ }^{11}$ Lyly undoubtedly conceived the play as a panegyric, and yet the playwright's professional and social vulnerability to Elizabeth clearly undermines this conception. Commenting on this ever-present awareness of the queen's authority in Elizabethan England, Louis Montrose writes, 'It was inevitable that the rule of a woman who was unmastered by any man would generate peculiar tensions.. ${ }^{12}$ Even in praising the queen, Lyly responds to the danger that she represents by firmly isolating her from other women and establishing her as a policing force. In Endymion the greatest threat to women is not an accusation of monstrosity and malevolence but the potential powerlessness achieved through the erasure of the witch, a powerlessness that Cynthia avoids only by the happy accident of divinely granted perfection. 
Various early modern texts convey the desire of learned protestant writers to expose the hypothetical witches and healers as ignorant, deluded women who possess no power of their own. On the other hand, they also show that popular belief in the potency of these figures continued to exist and presented a difficult problem. This tension is evident in George Gifford's Dialogue Concerning Witches and Witchcraftes, published in 1593, some five years after Endymion's first supposed performance. In the course of the dialogue, wise M.B., serving as Gifford's mouthpiece, criticizes popular distinctions between witches and women healers, explaining to his interlocutor Samuel that there should be no difference in the treatment of the two, who are equally powerless and deluded by the devil. The grave conversation, however, waxes suddenly comical at the dialogue's end, when Goodwife R. enters the house: Samuel's wife, having listened more or less silently before that moment, exclaims to the visitor, 'I would you had come a little sooner, there was one even now that said you are a witch'. ${ }^{3}$ When questioned, she mockingly quotes M.B.'s own argument: 'Did he not say she played the witch that het the spit red hot and thrust it into her creame, when the butter would not come?'14

Goodwife R. is properly incensed at the accusation and argues that the charm involving the hot spit is not 'a thing taught by the divell' at all: she denies any interest in practising witchcraft and, indeed, expresses a wish that 'all the witches in the land were hanged and their spirits by them'. She explains that this most efficacious charm was taught by 'the good woman at R.H.' who, according to the goodwife, 'doth more good in one yeere then all these Scripture men will doe so long as they live'. To further questions about the origin of the charm, Goodwife R. replies with finality, 'It is a gift which God hath given her, I thinke the holy spirite of God doth teach her'.

In this exchange, M.B. makes an effort to blur the boundaries and collapse the categories altogether: witches, healers, and village women who believe in and distinguish between the two are not essentially different in their impotence and lack of guidance. ${ }^{15}$ On the other hand, Goodwife R. insists on clearly defining three categories of women: the malevolent witches, guided by their spirits and the devil; the benevolent healers, guided by God; and those women who, like herself, abhor witches but are eager to use the services and advice of healers. In this model of the world, all three positions are accessible to a village woman: the last one by default and the first two by choice. The local women do not see themselves as engaging in witchcraft but, in referring to the proliferation of witches around them, acknowledge 
that the position is wide open to them. While the witches are pictured as the enemy with whom no contact may be made, the boundary between the wives and the cunning woman of R.H. is permeable: having learned the charm, Goodwife R. is able to take on the role of a cunning woman and, by treating her 'bewitched' milk with a hot spit, fight the hypothetical witch who had laid the curse.

Gifford's heavily gendered Dialogue offers a concise account of a centuries-old struggle for power, closely tied to the increasing professionalization of medicine - the struggle that eventually found its expression in the project of merging the healer with the witch and draining both figures of power and authority. Jean Dangler traces the shift from the favourable representation of women healers in '[m]edical treatises, hagiographic literature, and Marian works' to the view of them 'as standing in opposition to the work of the learned male physician'. ${ }^{16}$ As 'the requirement of university study in a medical faculty' was introduced, women, who were prohibited from entering university, ${ }^{17}$ began to be described as inherently ignorant and capable of harm rather than cure. Recognition that licensed male practitioners were too few and too expensive to service all those who needed medical help only exacerbated the tension. ${ }^{18}$ The necessity of women healers was thus acknowledged, and their practice often tolerated, officially or unofficially, but their portrayal, both in fiction and in legal texts, grew progressively ominous. Religious women, previously portrayed as care-givers and tenders of the sick, now 'appeared more frequently in the role of the infirm' and were linked to disease and disability; ${ }^{19}$ women healers, even those belonging to the religious orders, were suspected of purposeful infliction of disease, especially on men, and of teaching other women how to feign and inflict illness. ${ }^{20}$ Although the licensing practices no doubt influenced male folk healers as well, active opposition to health and the threat of harm were seen as peculiar to women, both biologically and socially. ${ }^{21}$

By the end of the sixteenth century, the menace of women healers was firmly located not so much in their conscious intent — or ability — to inflict injury but in their utter unsuitability for bringing others back to health. This view is explicit in the case of Margaret Kennix, published in 1581 in 'the colleges proceedings against Empiricks and unlicensed Practisers': the writer refers to Kennix as 'an outlandish, ignorant, sorry woman'. ${ }^{22}$ The wording of the existing record suggests that Kennix not only does not possess the necessary qualifications that might be granted by an institution, but also belongs outside the medical field and must not claim credentials there. The term 'out- 
landish' is quite suggestive: according to the Oxford English Dictionary, this word could refer to bizarre appearance or behaviour but more commonly indicated someone who seemed foreign, unfamiliar, strange. Despite her long-term practice, the composer of the record sees Kennix as an alien to the medical sphere; the overtones of this description recall Reginald Scot's presentation of witches as bizarre, pathetic, powerless - and, of course, female.

And yet, as Gifford's treatise witnesses, women were not willing to part easily with the positions that, within the framework of growing separation between public and private spheres, offered an opportunity for authority. While this is undoubtedly a complex question, it does seem that from the sixteenth century onward women's ability to work and run businesses became more restricted, especially where craft guilds were involved, ${ }^{23}$ as was their ownership of property. ${ }^{24}$ Although Judith M. Bennett cautions scholars against idealizing the middle ages and urges greater focus on continuity, she does not challenge this basic assumption. ${ }^{25}$ As Mary Beth Rose puts it,

However it has been nuanced and complicated, though, the argument that early modern England experienced the beginnings of a more defined public-private division that clearly separates the genders, conflating what is masculine with what is public, becomes enriched rather than weakened. Even when detached from issues of progress or its lack, or considered in terms of the blurred boundaries between continuity and change, the larger trajectory of the argument remains intact. ${ }^{26}$

The increasing association of women with the private sphere also meant greater emphasis on marriage which, after the last English nunneries were disbanded with Queen Elizabeth's accession to the throne, came to replace the medieval view of virginal life as a viable and even laudable option. Early modern women could choose not to marry; at the same time, single women 'were not permitted to live alone but had to reside in the households of their parents or married siblings. ${ }^{27}$ Women could be hired as maidservants, but while performing household duties for one's husband was laudable, being hired to perform these tasks for strangers was described as 'servile' and viewed with condescension. ${ }^{28}$ Subsumed into the private sphere, the ideal married woman occupied a space from which she exerted no influence on the outside world and, obedient to the natural hierarchy, silently accepted the rule of her husband. ${ }^{29}$ 
The women in Gifford's treatise have no desire to accept this model and seem to rely on the existence of both witches and cunning women to claim authority and a voice within marriage. The persuasive M.B., whatever his success with Samuel, is unable to influence the women's opinion on the matter. Samuel's wife offers only two sarcastic remarks, but Goodwife R. loses all patience and, having already accused M.B. of taking the witches' part, now cuts the conversation short: 'What tell you me of Gods word: doth not Gods word say there bee witches ...? Are you a turne coate? Fare you well, I will talke no longer with you'. 30 There is no doubt that the Goodwife is extremely vocal, has no scruples about offering Biblical interpretation, however disapproving of her interpretations Gifford is, and, finally, has absolutely no intention of giving up her position of power. When her status as a qualified witch fighter is threatened, she is quick to shift the suspicion of heterodoxy to the accuser. Gifford clearly ridicules those who share her views, and yet, with Goodwife R.'s dismissal of M.B., the discussion ends. At the closing of the treatise, public opinion stands unconvinced; but, what is more, the two wives remain unsubordinated and unwilling to give up their problematic practices. Their lack of subordination manifests within the framework of protestant demonology but also within their marriages: as her two remarks suggest, Samuel's wife allows herself to disagree with her husband's opinion, while Goodwife R. speaks both for herself and her husband in this discussion. Although Goodwife R. is the one to use the counter-charm, she specifies that it was originally taught to her husband, ${ }^{31}$ who thus functions as a mere conduit for the knowledge that his wife then wields with authority. On the one hand, Gifford is obviously exploiting popular associations of shrewish wives with witches as a warning to those who might want to adopt a similar demeanour, but on the other, Goodwife R. emerges victorious, having made her opinion known.

The question of female power, specifically related to issues of witchcraft, restorative abilities of women, and marriage, permeates early modern texts and becomes especially pointed when Elizabeth I ascends to the throne. Various scholars, beginning with Montrose, have spoken of the acute anxiety caused by this inversion of the natural hierarchy, an anxiety which intensified in the 1580s, after the termination of the French courtship, with the realization that the queen was never going to marry and produce an heir. The figure of the witch, in itself signalling a disruption of the natural order, becomes a useful symbol for this anxiety in the early modern drama and yet it is a symbol that must be read, considering Lyly's position and audience, 
in the light of the current protestant discussion. Although in her important study Diane Purkiss seeks to separate the theatre both from scholarly discourse and from the popular belief structures, contending that 'Dramatists are less interested in witches ... than they are in their own identities when they produce their witch-figures, ${ }^{32}$ this approach seems to discount the cultural and social building blocks of theatre. Rather, as Clark suggests, conceptions of witchcraft must be treated as 'an ideological and cultural resource', with 'an awareness of witchcraft's great symbolic and metaphoric power'. 33 Lyly brings the witch on stage as an embodiment of female corrupting disobedience but in the light of the protestant witchcraft debate, this symbol is highly unstable and must disintegrate, revealing the true source of trouble in the world of the play.

In the destabilized community of Endymion, the witch Dipsas is little more than the means for performing some of the problematic actions: this performance serves to indicate that the appropriate pattern of female behaviour has been seriously disturbed. The play makes it clear that such a pattern does, in fact, exist and all women in the play recognize it, but simple realization of these virtues is not enough. Without concentrated effort and firm self-governance, common feminine flaws interfere in the normal functioning of the community and cause disruption in personal relationships. So great is this interference in Endymion that the play usually reminds its audience of the behavioural norms only as they are being broken.

Even Tellus, the epitome of female disobedience, freely admits to the audience that 'to dissemble' is 'most contrary to [her] sex' (4.1.30-1) — and immediately embarks on a deceptive scheme in which, pretending to love the general Corsites, she sets him the impossible task of moving the sleeping Endymion. Left alone, she first attempts to justify herself by explaining that such designs are familiar and expected in dealing with men, who refuse to accept rejection and continue to expect submission. If a woman does not distract her lover with unattainable goals, she 'should be cumbered with importunities, oaths, sighs, letters, and all implements of love, which, to one resolved to the contrary, are most loathsome' (84-7). In the very next line, Tellus has abandoned all regret at her deception and is about to 'go in and laugh with the other ladies at Corsites's sweating' (87-8). Tellus, in other words, is being doubly deceptive: first, in feigning affection for hapless Corsites and promising him her love in return for doing the impossible and, second, in affecting, if only for a minute, genuine regret for the benefit of the audience. The wording links the rapid disappearance of this regret to Tellus's 
intention to join a group of other women, who will encourage her in both this dissimulation and the enjoyment derived from it.

As Tellus's example makes clear, female misbehaviour is entangled with the question of marriage and, even more so, with the desire to wield power over men. The audience must recognize that the normal process of courtship as understood in Elizabethan society has gone terribly wrong in the community of Endymion long before Dipsas appears on the scene. The male suitors are obviously incapable of controlling the independent and capricious behaviour of the women and fall prey to female manipulation. Even Eumenides, a noble and brave character, admits regretfully, when Semele in her contrariness methodically rejects all his overtures, that his beloved is 'of all women the most froward and [he] of all creatures the most fond' (3.4.62-3). While one can understand and forgive the young women's rejection of their suitors and even, to a certain extent, the equivocation to which they might be led by the men's persistence, ${ }^{34}$ the reversal of gender roles reverberates through the world of the play. According to Tellus's own definition, she plays the role of the male wooer in her relationship with Endymion: in the face of her persistence, he must pretend undivided love for her. ${ }^{35}$ When Tellus becomes aware that the attentions of her beloved lie elsewhere, she reacts in a manner 'far unfitting [her] sex, in which nothing should be but simpleness' (5.4.55): rather than admit defeat and lose control of the situation, she overpowers Endymion by contracting a witch's services to put him into eternal sleep, so that he might never belong to anyone else.

Clearly the women of Cynthia's court are either averse to the idea of marriage or quite unfit for it, and have the characteristics of bad wives familiar to an early modern audience: they are deceptive, disruptive, uncontrollable, and desirous of power. Endymion raises this concern in his very first onstage encounter with Tellus, dreading that, unless he conceals his devotion for Cynthia from her, she will 'be as suspicious as Juno' (2.1.52), the jealous, powerful, and vengeful wife of Jupiter. Closely connected to this concern is the apprehension of women's spiteful tongues; in sixteenth-century England, being a scolding wife had become a crime punishable by public humiliation, since it indicated the reversal of the natural familial hierarchy. ${ }^{36}$ The women of Endymion, in their desire to occupy the public sphere, do not know how to hold their tongues and, instead, speak incessantly and maliciously. This is evident even in the minor characters: the pages Dares and Samias purposefully set the maids Favilla and Scintilla against one another, encouraging them to quarrel and commenting, 'Let them to it, and we will warm us by 
their words' (2.2.24-5). The quarrel is a source of amusement for the men, but also seems to point to gender confusion when, observing the fighting maids, Samias calls them 'sparks' (23); this allusion to their names can also refer to young fashionable men. The implications are clear: being vocal and uncontained makes a woman an object of ridicule and lends her masculine characteristics, making her unsuitable for the role of proper wife. ${ }^{37}$

Not surprisingly, the only wedlock-conscious woman in the play is terrified of seeming talkative. Dipsas's servant Bagoa exclaims, to explain her fear of the witch: 'I dare not repine, lest she make me pine, and rock me into such a deep sleep that I shall not awake to my marriage' (2.3.59-61), and Dipsas, in turn, threatens to punish her not with sleep but by turning all her 'hair to adders and all [the] teeth in [her] head to tongues' (66). The multiplication of tongues in this threat recalls Medusa, a menacing woman bristling with phallic snakes, who will turn any man approaching her to stone. Cynthia strengthens this association further by expressing her doubt that any one would want to marry Semele, 'very wasp of all women, whose tongue stingeth as much as an adder's tooth' (5.4.206-8). What the obedient Bagoa fears, the women of Cynthia's court embrace; the play condemns them not for associating with the witch, and not for any hidden monstrosity, but for this, not uncommon for women, reaching for authority and influence.

In a world so troubled and concerned with trespassing, power-grasping women, Cynthia's own position appears unequivocal and precarious because of both this character's relationship to authority and her role as a healer. With a woman as ruler, the world of the play invokes the uneasy discourse created by the consecutive ascensions of two queens in England. If viewed primarily in the context of their gender, both Cynthia and her prototype are not qualitatively different from other authority-seeking women in the play, the manifestation of whose detrimental influence Dipsas becomes. One need only recall John Knox's treatise, which attributes to women in power quasi-magical capability for perversion and destruction. In The First Blast of the Trumpet Against the Regiment of Women, written during Mary Tudor's reign but published the year before Elizabeth's accession to the throne, Knox brands women rulers as tyrants and unnatural usurpers, lamenting, 'But woman being promoted in sovereign authoritie, her lawes must be obeyed, her opinion followed, and her tyrannie mainteined ... a woman promoted to sit in the seate of God, that is, to teache, to judge or to reigne above man, is a monstre in nature, contumelie to God, and a thing most repugnant to his will and ordinance. ${ }^{38}$ The possible consequences of being ruled by mon- 
strous queens are dire. If one were to see such an Amazon on the throne, he would not be able to help believing that 'such a metamorphosis and change was made of all the men of that countrie, as poetes do feyn was made of the companyons of Ulisses', although in this case the metamorphosis might be limited to the men's hearts, while 'the owtwarde form of men remained' 39 The destruction will not necessarily stop at male morale, since, Knox warns, women are capable of anything and 'some have killed with crueltie their owne husbandes and children'. ${ }^{40}$

Although Knox does not name the women to whom he is alluding, the subject of the first reference is certainly Circe, who turned some of Ulysses' men into swine, and a classical infanticide familiar to him would be Medea, the avenger of her husband's desertion. As Purkiss points out, however, the main interest in Medea does not necessarily spring from the murder of her children: she is also known for betraying her royal family and thus her country of birth, as well as for restoring youth to Aeson by magical means. ${ }^{41}$ In light of these transgressions, she is viewed as an unnatural force, the disrupter of order, the one who 'transforms what is into its opposite' 42 - in other words, a witch. Similarly, Circe has a long standing place in the discourse of witchcraft and demonology, particularly in relation to the question of whether witches can in fact change their and others' outward shapes. ${ }^{43}$ Knox's treatise links the woman ruler to the figure of an enchantress-cum-witch, whose power is specifically directed at men and has sexual overtones, but underneath the sexual promise lurks the threat of radical alteration and eventual destruction. If even Mary, married and much preoccupied with producing an heir, could have given rise to these allusions, how much more appropriate were they for Elizabeth, especially after it became clear that she was going to remain single? As that monstrous thing, the woman ruler, she contained a promise of dangerous power; by her very existence, she transformed the world. Certainly Berry and Neufeld are correct in postulating a link between Cynthia and Dipsas; but this link is presupposed by her position and the discourse generated by her prototype rather than argued by Lyly.

The connection, furthermore, is aggravated by Cynthia's role as healer - an occupation which, as I have shown, had grown closely intertwined with the pursuits of witches and with the idea of women laying claim to knowledge and ability beyond their ken. This intertwining is evident even in the classical references since, through her transformative powers, Circe could also give back their former appearance to Ulysses's companions, and Medea was able to restore youth to Jason's father, just as Cynthia does for Endymion. 
Queen Elizabeth herself entered into the position of a woman healer both through her association with these figures and through her participation in the cure of King's Evil by royal touch. In the laudation that ends Euphues and his England (1580), Lyly calls Elizabeth 'a physician to the sick', ${ }^{44}$ suggesting that the idea of healing is implicit in her position; like any implicit trait, it may be variously interpreted. Clark persuasively argues for a striking overlap between the actions of common practitioners of magic and the healing performances of rulers; ${ }^{45}$ he points out that 'contemporaries too realized that the actions of kings and witches could be sufficiently cognate for them both to be suspected of demonism'. ${ }^{46}$ The association in this case must have been exacerbated by Elizabeth's gender and the tenuousness of her position as the hereditary ruler of England, first with the suspicions of bastardy and, by the 1580 s, by the lack of an official heir to the throne. Indeed, the similarity was so apparent to an outside observer that Jesuit Martin Del Rio accused the queen, with her claim of healing abilities, either of witchcraft or fraud, echoing, perhaps unwillingly, the evolution of protestant attitudes toward cunning women. ${ }^{47}$

An obvious path of defending Elizabeth against these allegations would mean rethinking early modern attitudes toward women and their place in the society; instead, contemporaries suggested that Elizabeth alone was exempt from the requirements of social order by a special dispensation. In responding to Knox's rebuke of women rulers, for example, John Aylmer argues that 'when God chuseth him selfe by sending to a king, whose succession is ruled by enheritaunce and lyneall discent, no heires male: It is a plain argument, that for some secret purpose he myndeth the female should reigne and gouerne'. ${ }^{48}$ The marginal note summarizes his point: 'God worketh in weakness. ${ }^{49}$ While elsewhere in his treatise Aylmer refers to women governing successfully in the past, the overtones of his argument are not crucially different from those of Knox: in light of the natural hierarchy, weak women are not meant to be rulers, and only 'some secret purpose' of God can justify such inversion. In essence, Elizabeth's position as the queen of England is a miracle: it reveals God's will but does not set precedent.

Lyly's treatment of Cynthia in Endymion, then, mimics arguments such as Aylmer's. In her role as a healer and an influential woman, Cynthia is suspect by default; her power and ability to transform the world are not qualitatively different from the power that other women in the play seek. In writing the play Lyly must cope with the continued existence of women healers and, even more so, with the continued existence of Elizabeth, a woman who can 
heal through touch and on whom his career at court hangs. Cynthia cannot simply disappear; instead, she is literally raised above suspicion. As the moon, Cynthia is placed in the curious liminal position of being in constant close contact with the sublunary world but ultimately remaining superior to and untainted by it. The play suggests that Cynthia possesses the power of healing precisely and exclusively because of the inimitability of her virtues, which reside well out of reach. When the sacred fountain prophesies that Endymion is to be healed by Cynthia 'whose figure of all is the perfectest and never to be measured' (3.4.166-7), Geron, the wise man of the play, exclaims, 'Is not a circle of all figures the perfectest? ... And is not Cynthia of all circles the most absolute? ... Is it not impossible to measure her, who still worketh by her influence, never standing at one stay?' (177-82). The perpetual flux of the moon not only completes her flawless virtue and makes her divine, but also renders futile any attempt at locating and imitating this virtue. Because, as Endymion tells jealous Tellus, Cynthia's 'virtues are not within the reach of [human] capacities' (2.2.86-7), her 'perfection alloweth no companion nor comparison' (2.1.29).

This laudation of Cynthia owes a great deal to epithets commonly used to describe Queen Elizabeth and the references are clearly meant to be immediately recognizable. The use of lunar imagery to refer to Elizabeth is not unique to Lyly, as the queen plays the role of Diana, associated with the moon, or Cynthia, an aspect of Diana, in various portraits and entertainments. ${ }^{50}$ In glorifying Cynthia as the ultimate restorer of the natural order, Lyly also seems be linking his main character to the Virgin Astraea, or Justice, who had departed from the earth when the original order had been destroyed. Now that the reign of Elizabeth I brings back the Golden Age, Astraea returns to the earth; alternatively, Elizabeth herself is seen as Astraea, the perfect ruler. ${ }^{51}$ This imagery is not necessarily unified and sanctioned by the queen herself, as Frances Yates originally argued; in his recent book Montrose shows that the various representations of Elizabeth could differ quite drastically and 'were themselves particular constructions' of her gender. ${ }^{52}$ In Endymion, Lyly emphasizes the distant, untouchable quality of Cynthia, who never quite returns to the earth completely. Indeed, the elevated position which Cynthia occupies in Endymion is not unprecedented in the images produced during Elizabeth's reign. For example, the frontispiece of John Case's Sphaera civitatis - which was, incidentally, published in 1588, the year when Endymion was likely first performed — places the queen outside of the Ptolemaic universe, embracing and ruling the cosmic world. 
As Andrew and Catherine Belsey point out, while diagrams of this type are not particularly rare and do usually present their human subject enjoying 'some superiority over the non-human universe', in them 'the human figure is always within the universe; it is enclosed by it, encompassed by it. If it rules, it rules from within. ${ }^{53}$ In this diagram, by contrast, Queen Elizabeth remains an earthly ruler but embraces the universe from the outside, clasping the entire creation to her bosom. ${ }^{54}$ This image is paralleled in the play, as Endymion, standing on the ground, gazes at his beloved residing in the stars and laments that the stars - and she — 'being as high as [he] can see' are also completely out of his reach (1.1.6-7). The queen does not disappear from her subjects' vision: she looms large on the horizon but remains elusive, veiled by her perfection and significance. In a very real sense, Lyly's Cynthia is a pre-existing fantasy of Queen Elizabeth that has been given a world in which its imaginary attributes may be re-enacted; conversely, the function that Lyly proposes for Cynthia in the world of the play points to the role he envisions for Elizabeth in court.

The restorative, salvific element of the queen's powers had already figured prominently in performances staged for Elizabeth's benefit, where she entered the action or was represented as a benevolent enchantress, capable of releasing other characters from their magical captivity. ${ }^{55}$ While Cynthia's healing powers are indisputable, all the major acts of healing she performs in the course of the play are, significantly, meant to counter the original bewitchments cast by Dipsas. Her authority, in other words, is reactive, since Cynthia chooses to influence the world only faced with distortions of natural order. The first of these distortions is Endymion's unnatural sleep: Cynthia awakens her courtier, whose eyes, otherwise, can 'be opened neither by art nor nature' (2.3.33-4) with a kiss of her previously untouched mouth. When the awakened Endymion confesses a most courtly love to her, Cynthia announces: 'those that neither my favour can move to continue constant, nor my offered benefits get to be faithful, the gods shall either reduce to truth or revenge their treacheries with justice' (5.4.182-5). In her healing acts, then, Cynthia channels the 'true' picture of the world onto those who have defected from it; the transformations she effects are acts of restoring natural justice rather than justice which she herself might consider necessary. This supposition is reaffirmed when Cynthia commands to her faithful courtier, 'Endymion, continue as thou hast begun' (185-6), urging him to persist in his devotion and, at the same time, editing out the disruptive moment of Dipsas's enchantment. This declaration of her favour is enough to per- 
form the act of healing and restore youth to the courtier, making his 'joints strong, and these mouldy hairs to moult' (189-90). The third act of healing is also one of reversion - returning Bagoa, Dipsas's former servant, to her original shape. Again, this is achieved not by any specific action nor even a direct command, but simply by Cynthia's statement of her intentions. She addresses the tree, 'Bagoa, Cynthia putteth an end to thy hard fortune, for, being turned to a tree for revealing a truth, I will recover thee again if in my power be the effect of truth' (295-7). The tree, of course, obliges. The wording of the last address stresses the crucial difference that Lyly sees between Cynthia and those of Medea and Circe's ilk: while Medea and Circe distort the truth, Cynthia counters the bewitchment and heals Bagoa by appealing to the natural order and allowing that which has been perverted to spring back to its original shape. ${ }^{56}$

And yet, although these miraculous acts establish Cynthia as a healer, they primarily work to deal merely with the symptoms of disorder rather than with the cause. By the middle of the play the audience must recognize that Dipsas's enchantments serve as a manifestation of other women's grasping for influence and, ultimately, are just as unnatural and ineffectual. The trinity composed of the healer, the witch, and other married or marriageable women collapses not because all women are exposed as potential witches but because, once the subject of marriage is developed, there is very little distinction to be made between Dipsas and the other potential wives. To be sure, the malevolent feats Dipsas performs in the play — sinking Endymion into such heavy sleep that he cannot be moved and turning Bagoa into a tree, in the best Ovidian traditions - are impressive and point to her great power; indeed, she claims that her enchantments can be undone 'neither by art nor nature' (2.3.32-3). It seems, at least in the beginning, that Dipsas is truly the frightening malefica whose existence protestant writers denied so persistently, and her work within the play, appropriately, is directed toward helping Tellus take control over Endymion. The connection between witches and shrewish, problematic women has been noted before: in many post-reformation texts, witches encourage and aid the discord and power struggle within the family. ${ }^{57}$ In accordance with this tradition, in Endymion the witch supports and strengthens female disobedience and seems to offer, in her knowledge of magic, a position of power that is open to every woman.

The impressive figure of the malefica, however, begins to be eroded in the middle of act three when, in a comic subplot, Sir Tophas falls in love with Dipsas and seeks to win her hand in marriage. There is absolutely no indica- 
tion that Dipsas is ever aware of his intentions; the entire courtship takes place over three acts in the form of an assessment of the witch as a possible wife by four men. In the process of this evaluation, the features that are frightening and distinguishing in a witch become simply pitiful and laughable in a prospective wife. In particular, the men comment on her ugliness which, within this framework of evaluation, will not instil reverent fear in others but will rather keep Dipsas from opportunities to cuckold her husband and crown with laurels of courage the man who brings himself to marry her. 'How virtuous is she like to be, over whom no man can be jealous!' exclaims Sir Tophas (3.3.63-4) and Epiton chimes in: 'Without doubt all the world will now account him valiant, that ventureth on her whom none durst undertake' (73-5). The only question that may be asked of such a woman is: 'Will she yield? Will she bend?' (5.2.57-8), which hints both at sexual availability and at wifely submission to her husband. The answer, in this case, is negative; according to the page Dares, Dipsas herself is entirely unsuitable for marriage, partly because of her appearance and age but also because she is 'a scold' who will 'rail' and 'crab' $(3.3 .96,106,108)$. Even the epithet 'black saint', applied to Dipsas several scenes later (4.3.36), falls flat. While it could potentially present her as a powerful counter-force to Cynthia's saintly purity, Epiton uses the term as proof that Tophas's poetry to the witch should be set to the tune of 'the Black Saunce' (35). This line, as David Bevington notes, references 'Black Sanctus, a parodic hymn to Satan in ridicule of the monks' which was also 'sometimes used of any discord of harsh sounds of profane ditty such as might be used to serenade a faithless wife. ${ }^{58}$

Finally, in act five the audience discovers what was being implied all along: Dipsas not only has the potential to be a bad, shrewish wife but already is one, having banished her husband by black magic 'to live in a desert, almost desperate' (5.4.18-9). This piece of information is in itself inconsistent with what is known of English witches: records from Essex and Kent show that, among accused witches, the percentage of married women is significantly lower than of those who are single or widowed. ${ }^{59}$ Dipsas's married state thus makes her a highly untypical witch, or perhaps not a witch at all, or at least not a figure of any significance, since the discovery of her marital status causes Sir Tophas to lose interest in her instantly.

By the end of act five Dipsas has dwindled into a nonentity that not only cannot oppose Cynthia but also is disregarded by the rest of the characters. Cynthia tells her, 'Breathe out thou mayst words, gather thou mayest herbs, find out thou mayst stones agreeable to thine art, yet of no force to appal 
my heart, in which courage is so rooted ... that all thy witchcraft I esteem as weak as the world doth thy case wretched' (11-16). These words reduce Dipsas's enchantments from the magnificent, world-shaking deeds of a classical witch to the more prosaic search for plants and rocks; she has become one more 'wretched' wife, breathing out words that have no power over the world. Although Lyly does not deny the possibility of female authority, this authority is permitted only to Cynthia, the miraculous and distant entity, effectively erasing the position of the powerful witch.

Furthermore, the play reinforces the gap between the Moon and the other women characters by establishing Cynthia as the policing force: to heal the natural order, she compels other female characters to assume their 'proper' roles in the private sphere. Berry has argued that Lyly relegates Cynthia to 'the space which the female monarch shared with other women', to 'the private, emotional and feminine sphere of experience', and thus limits her public authority and political power. ${ }^{60}$ Cynthia, however, is very far from any kind of 'sharing' of space and experience with other women, from whom she is so clearly isolated by her perfection; ${ }^{61}$ as the play and John Case's diagram make clear, Cynthia and her prototype might spend most of their time at court but they rule the universe. The main function of this rule in Endymion, it seems, is to circumscribe the potential of other women and to police any instances of disobedience, especially those traditionally associated with bad wives.

Cynthia is particularly concerned with the women's unruly speech, which is both a sign of their unwillingness to withdraw into the private sphere and a tool of resisting such withdrawal, since inappropriate words are primarily directed against men and marriage. The first scene of the third act sets out this dynamic in some detail. Having discovered that Endymion has been sunk into magical sleep, Cynthia is concerned with his welfare, while Tellus and Semele are gleeful and rather explicit about their glee. At first, Cynthia is merely surprised at what she hears and wonders, 'What maketh you, Tellus, to be so short?' (3.1.8). Later, when Semele allows herself to mock Eumenides's own speech and quips that his 'speech beginneth to be so heavy' (13) that he had better go to sleep with Endymion, Cynthia grows displeased with their 'unseemly and malapert overthwarts' (16-17). Emphasizing her role as the regulating force for 'proper' behaviour, she threatens to 'tame your tongues and your thoughts, and make your speeches answerable to your duties' (17-19). This threat seems to apply to all the banterers, regardless of their gender; but while the men's duty in this case is to travel and speak, ${ }^{62}$ the women's, by contrast, is to keep silent. 
Cynthia's role in the play is not to avenge specific misdeeds but to remove the very source of disobedience. Not for employing a witch to put Endymion to sleep but for speaking against him, Tellus is enclosed in a castle and ordered to weave stories or poetries, with 'examples infinite in either, what punishment long tongues have' (45-6). This is very much an instructional moment: not only must Tellus partake of the 'infinite' moral lessons on the subject of speaking overmuch, but she herself will become just such a lesson for other women, when Cynthia purposes to 'make [her] tongue an example of unrecoverable displeasure' (41-2). Semele recieves even harsher measures when, in a further discussion about the sleeping Endymion, she refuses to speak favourably of him and demurs, 'I dare say nothing for fear I offend' (4.3.68). If Semele will not speak, her very thoughts must be regulated; noting that it is 'as good be silent as saucy' (70), Cynthia is troubled by Semele's refusal to offer the praises that are being demanded of her and concludes with displeasure that the woman does not possess the appropriate mildness and 'cannot speak except [she] be spiteful' (69). For having, in the most unwomanly fashion, 'only contempt and sourness' in her 'speech and thoughts' (71-2), Semele must be punished. The philosopher Panelion advises that Cynthia 'commit her tongue close prisoner to her mouth (74-5); presumably, this silence would be mild and penitent. Cynthia enthusiastically agrees and adds that, if Semele allows herself to become vocal during the next year, she will 'forfeit [her] tongue' (77).

Silence indicates Semele's newly forged suitability for marriage and, at the same time, serves as a tool to push her into conjugal union with Eumenides. In the absence of speech, it is assumed that she is 'content after so long trial of his faith, such rare secrecy, such unspotted love, to take' him (5.4.212-14). The proposal of marriage turns into a frightening charade when the court, well aware of the constraints that hang over Semele, ${ }^{63}$ conspires to interpret her desperate silence as wholehearted acceptance. Eumenides, the fond lover, is quite content to inscribe his own desires on Semele's enforced passivity and exclaims eagerly, 'Silence, madam, consents. That is most true' (215). The truth, then - and Cynthia is much concerned with truth in this play - lies not in Semele's own wishes but in the actions she undertakes under the threat of bodily harm. Semele resists this interpretation to the end, finally speaking, in full disregard of the prohibitions, to refuse the undesired marriage partner, 'A hard choice, madam, either to be married if I say nothing or to lose my tongue if I speak a word. Yet I do rather choose to have my tongue cut out than my heart distempered. I will not have him' (220-3). This final refusal 
to consent in silence and become a good wife marks Semele as an incorrigible woman who, in Cynthia's view, cannot be put to any good use and must be destroyed: 'Speaks the parrot? She shall nod hereafter with signs. Cut off her tongue, nay, her head, that ... will not be persuaded' (224-7). Semele, of course, is not executed: she is saved by Eumenides's willingness to 'let [his] tongue ransom hers' (235-6) and, in gratitude, assents to be wed to him. In essence, then, there is an exchange of tongues, in which the tongue of Eumenides will, from now on, stand in for his wife's. Semele loses speech after all, if not physically then metaphorically, as she becomes a grateful wife and is relegated to the private sphere: she speaks no more in the play.

According to early modern understandings of female anger, Semele has paradoxically been declaring her need for such silencing by re-enacting her spite, since 'a woman's anger is a sign of weakness that confirms her innate inferiority and her need to submit to male authority. ${ }^{64}$ Such a context explains the headstrong Semele's immediate agreement to accept, literally, Eumenides's tongue instead of her own. In keeping with Lyly's model of womanhood, her attempts at rebellion indicate desire for total submission, a desire which could not have been gratified by a fond lover but is answered by the appointed keeper of her mouth. Semele's transformation from a loquacious, headstrong woman who rejects her lover's advances into a silent, acquiescing wife traces the restoration of the natural order in the world of the play. It is a characteristic of the original problem that the men are incapable of asserting their masculinity and effecting such a transformation; instead, it falls to Cynthia to write the women back into their proper sphere.

In the world of Endymion, marriage becomes the ultimate answer to every rift in the social fabric: because, with the sole exception of the unique female ruler, powerful women do not exist; their disobedience is taken as the expression of feminine weakness. The major female characters are 'fixed' when Cynthia, in accordance with her role, heals the communal order by distributing the women to those men who agree to have them. Tellus agrees to marry Corsites in order to 'receive pardon for all that is past' (5.4.254). Even Bagoa, previously so worried that Dipsas's enchantments might prevent her from marriage, is given to Tophas, who 'cannot handsomely go to bed without' her (286). As with the other matches, Bagoa's agreement is assumed rather than sought; one cannot help but wonder if this is really the marriage of which she had dreamed. More significantly, Dipsas, until now 'wedded to that wickedness' of witchcraft, must 'forswear that vile art of enchanting' and, abandoning her symbolic marriage to power, or at least to some semblance 
of power, return to her proper husband Geron who 'hath promised again to receive' her, after fifty years of separation (5.4.269-72). The play thus completely effaces the figure of the witch; the audience is given to understand with finality that Dipsas is nothing more than a bad wife, ultimately impotent in the face of natural order, while Cynthia miraculously stands above the natural order by the virtue of her status as the Moon.

As Berry and Neufeld have suggested, Dipsas and Cynthia are unbreakably connected: the Moon's miracles carry a hint of witchcraft and even the rejuvenation of Endymion is reminiscent of one of Medea's enchantments. Like witches and like wives, she changes the world through words; her role as a healer is in itself suspect. Because Cynthia is unique, in her and only in her these implications may be forgiven, just as Elizabeth, in Lisa Jardine's argument, is cleansed from 'the taint of her sex' through becoming a female personification of virtue. ${ }^{65}$ And yet, the threat of this connection remains - a threat to Cynthia and, by implication, to Elizabeth, rather than to those around her. In losing her unique position, Cynthia will coalesce with Dipsas, the healer will merge with the witch; but since the witch has been erased, in entering this category Cynthia will grow not monstrous but impotent, indistinguishable from the other women of the court. The female ruler's position is thus highly precarious, as it is, by definition, an exception and hinges on an assumption of divine sufferance. According to Lyly, then, Cynthia must relentlessly impose the model of the early modern womanhood onto her ladies-in-waiting, whose sphere of influence must shrink as Cynthia's authority grows. Presented as a panegyric, Endymion is to a large extent a didactic play, written to deal with the powerful witch of the public imagination and with female disobedience but also to remind the queen of her problematic position and to urge that she might circumscribe her behaviour accordingly, so as not to lose her exceptional status. Considering that Lyly was seeking preferment, this urging probably indicates his umbrage at Elizabeth's solicitous treatment of her favourites, whom she promoted and showered with gifts. After all, Cynthia maintains her exceptional position by dispensing just rewards for her courtiers' affection and dedication instead of singling out the objects of her own affection.

How did Elizabeth interpret Endymion when it was presented to her? There is no record of her official response, but it seems that she recognized the veiled warning, not dissimilar to the admonition offered by John Stubbs in The Discovery of a Gaping Gulfin 1579, at the high point of the French marriage negotiations. Maintaining a tone of admiration for the queen, Stubbs 
poured scorn on her prospective husband, 'the old serpent in shape of a man, whose sting is in his mouth, and who doth his endeavor to seduce our Eve, that she and we may lose this English paradise'. ${ }^{66}$ The implication was clear. While Elizabeth was by virtue of her position an exceptional woman, she still remained the daughter of Eve; if she refused to listen to the well-meaning advice of her male subject, she would re-enact the fall from Paradise and, in doing so, join the ranks of other women tainted by original sin. ${ }^{67}$ Elizabeth's answering proclamation showed that this meaning did not escape her: although enraged by Stubbs's treatment of the French duke, in the end she declared herself 'grievously offended, with such a lewd denunciation to the people, by so common a false libel ... of the manifest lack of Her Majesty's princely care (if she should mind to marry)' ${ }^{68}$ The offense, it seems, lay in the suggestion that the intention to marry might impair Elizabeth's role as ruler of the realm and, therefore, that her position as ruler, in light of her gender, was rather precarious and easily destabilized by personal choices.

The outcome of such royal displeasure is well known: Stubbs was arrested, sentenced to have the offending right hand removed, and, after the sentence was carried out, held in prison for another year and a half. By constrast, Elizabeth's response to Lyly is largely characterized by her lack of response; while she did not react negatively, she also did not follow up on her promise of promotion, which was given at some point between 1585 and 1588 - before or around the time of Endymion's composition. ${ }^{69}$ Lyly never did obtain the position of master of the revels; he was not granted even the status of master in reversion - a patent that would ensure the position for him once its current holder died. ${ }^{70}$ Moreover, in 1590 Paul's boys, the players on whom Lyly solely relied for the performance of his plays, were officially prohibited from acting for approximately ten years. As G.K. Hunter points out, it is difficult to assess what part Elizabeth played in this injunction; in any case, she did not choose to defend Lyly when his satirical drama caused offence. ${ }^{71}$ His two extant petitions to the queen betray painful disappointment: in the first, he writes of his 'sad and settled devotion' and 'a repentance that [he has] played the fool so long, and yet [lives]'. ${ }^{72}$ In the second petition, dated 1601, he refers bitterly to 'a thousand hopes, but all nothing; a hundred promises, but yet nothing. ${ }^{73}$ Having written in Endymion an admonition to womankind in general, and to the queen in particular, Lyly had to spend the rest of his life in constant and humiliating recognition of Elizabeth's power over him, as unjust as, in his view, her exercise of this power might have been. 
Elizabeth was not, and did not become, the ideal, disembodied queen whom Lyly envisioned: she had favourites throughout her reign and was rumoured also to have had lovers and to have given birth to several children. ${ }^{74}$ Her body and her gender came into especially sharp focus in the last decade of her reign, when the aging queen was accused of vanity and mocked by some for her desire to remain attractive despite the passage of time. ${ }^{75}$ But even as an imperfect woman she retained her authority and influence and, even after her death, was called the good Queen Bess, the healer of her state and of her people. While Lyly could construct what he saw as the proper order in Endymion and circumscribe flawed women to the private sphere, he could not enforce it on the world around him: women continued to lay claim to power, and the shadow of Queen Elizabeth witnessed that such power was possible.

\section{Notes}

1 John Lyly, Endymion, ed. David Bevington (Manchester, 1996). All quotations from Endymion, cited parenthetically in the essay text, are to this edition. There seems to be some disagreement as to when the play was written and first performed. In his introduction Bevington shows that the first mention of its performance must be dated to 1588 ; others have argued that this means only that the play was written no later than the recorded year and could have been performed earlier with no record being retained. See Bevington's introduction to the play, 7-9, for a brief summary of the critical debate.

2 While some critics have assumed that Lyly had inverted Ovid's story of the moon's passion for Endymion, Susan D. Thomas convincingly shows that his source is Pliny's version of the myth, in which Endymion is rumoured to love the moon. See Thomas, 'Endimion and Its Sources', Comparative Literature 30.1 (1978), 37-8.

3 Philippa Berry, Of Chastity and Power: Elizabethan Literature and the Unmarried Queen (London and New York, 1989), 129.

4 Christine M. Neufeld, 'Lyly's Chimerical Vision: Witchcraft in Endymion', Forum for Modern Language Studies 43.4 (2007), 355.

5 Berry, Of Chastity and Power, 131.

6 Stuart Clark, 'Protestant Demonology: Sin, Superstition, and Society (c. 1520c 1630)', Bengt Ankarloo and Gustav Henningsen (eds), Early Modern European Witchcraft: Centres and Peripheries (Oxford, 1990), 59-62. For a discussion of protestant scepticism see, for example, Sydney Anglo, 'Reginald Scot's Discoverie 
of Witchcraft: Scepticism and Sadduceeism', Sydney Anglo (ed.), The Damned Art: Essays in the Literature of Witchcraft, (London, 1977), 106-39, and Christopher Baxter, 'Johann Weyer's De Praestigiis Daemonum: Unsystematic Psychopathology', in Anglo, The Damned Art, 53-75.

7 Reginald Scot, The Discoverie of Witchcraft (New York, 1972), 7.

8 Henricus Institoris and Jacobus Sprenger, Malleus Maleficarum, vol. 2: The English Translation, ed. and trans Christopher S. Mackay (Cambridge, 2006), 351. The Latin text reads: 'sed hoc communiter practicatur quod tales maleficiati currunt ad mulierculas superstitiosas, a quibus sepissime liberantur et non per sacerdotes aut exorcistas: ergo practica ostendit quod auxilio demonum maleficia tolluntur' (Ibid, vol. 1: The Latin Text, 493).

9 This does not mean that all folk healers and accused witches were, in fact, women; early modern records show that men could be and were accused of witchcraft and could and did act as folk healers. However, both the popular imagination and the learned treatise writers tended to see the healer and the witch as women. In the first chapter of his Discoverie, Scot speaks of 'certeine old women here on earth, called witches' (1), and George Gifford's Dialogue Concerning Witches and Witchoraftes, which I will discuss in more detail, strives to refute the existence of specifically female witches and female counter-charmers.

10 Berry, Of Chastity and Power, 111.

11 That Elizabeth I would not marry and produce an heir became abundantly clear in 1581, when the marriage negotiations with the French broke off; see Carolly Erickson, The First Elizabeth (New York, 1983), chapters 26-8, and Carole Levin, The Heart and Stomach of a King: Elizabeth $I$ and the Politics of Sex and Power (Philadelphia, 1994), chapter 3, for a more detailed discussion of the queen's last courtship. To a certain extent, Endymion is a reaction to the realization that that Elizabeth would remain the virgin queen.

12 Louis Montrose, 'The Shaping Fantasies of Elizabethan Culture', Margaret W. Ferguson, Maureen Quilligan, and Nancy J. Vickers (eds), Rewriting the Renaissance: The Discourse of Sexual Difference in Early Modern Europe (Chicago and London, 1986), 68.

13 George Gifford, Dialogue Concerning Witches and Witchcraftes (London, 1931), N3.

14 Ibid. Although Samuel's wife speaks only one more time in the remaining pages of the treatise, she seems to be on her friend's side and rather sceptical about M.B.'s propositions. The quotations that follow in this paragraph and the next are also from N3.

15 This total blurring of boundaries is supported when Gifford has Goodwife R., exasperated by M.B.'s insistence that there are no witches, remark speculatively: 'I would 
your nagge might hault a little one of these daies: see whether you would not be glad to seeke helpe' (Ibid, N4). This malevolent wish, unsurprisingly, recalls curses in the witch stories.

16 Jean Dangler, Mediating Fictions: Literature, Women Healers, and the Go-Between in Medieval and Early Modern Iberia (London, 2001), 9, 34.

17 Ibid, 35.

18 Ibid, 44-5.

19 Debra L. Stoudt, 'Medieval German Women and the Power of Healing', Lilian R. Furst (ed.), Women Healers and Physicians: Climbing a Long Hill (Lexington KT, 1997), 24-5.

20 See Michael Solomon, 'Women Healers and the Power to Disease in Late Medieval Spain', Furst, Women Healers, 79-92.

21 So, in Pliny's description, to which Bartholomaeus Anglicus refers, 'the glance of a menstruating woman discolors a mirror and causes wine to sour, buds to drop, and dogs to go mad'; see Clarissa Atkinson, The Oldest Vocation: Christian Motherhood in the Middle Ages (Ithaca and London, 1991), 40.

22 Qtd in William Kerwin, 'Where Have You Gone, Margaret Kennix? Seeking the Tradition of Healing Women in English Renaissance Drama', Furst, Women Healers, 93.

23 See Merry E. Wiesner, 'Women's Defense of Their Public Role', in Mary Beth Rose (ed.), Women in the Middle Ages and the Renaissance (Syracuse, 1986), 1-27.

24 See Amy Louise Erickson, Women and Property in Early Modern England (London and New York, 1993).

25 Judith M. Bennett, 'Medieval Women, Modern Women: Across the Great Divide', David Aers (ed.), Culture and History, 1350-1600: Essays on English Communities, Identities and Writing (Detroit, 1992), 145-75.

26 Mary Beth Rose, Gender and Heroism in Early Modern English Literature (Chicago, 2002), xi.

27 Retha Warnicke, 'Private and Public: The Boundaries of Women's Lives in Early Stuart England', Jean R. Brink (ed.), Privileging Gender in Early Modern England (Kirksville MO, 1993), 133. Warnicke traces the 'trajectory' identified by Rose well into the seventeenth century.

28 Ibid.

29 On the subject of 'proper' behaviour of women see, for example, Karen Newman, Fashioning Femininity and English Renaissance Drama (Chicago and London, 1991), chapter 1.

30 Gifford, Dialogues, N4.

31 Ibid, N3. 
32 Diane Purkiss, The Witch in History: Early Modern and Twentieth-Century Representations (London and New York, 1996), 183.

33 Stuart Clark, 'Introduction', Stuart Clark (ed.), Languages of Witchcraft: Narrative, Ideology and Meaning in Early Modern Culture (London, 2001), 6.

34 In this at least, Tellus has good precedent: in Geoffrey Chaucer's The Franklin's Tale, the virtuous wife Dorigen, driven to desperation by Aurelius's courting in the absence of her husband, sets him the task of removing all the stones from Britain and from the rivers Gironde and Seine.

35 Endymion's actions in response to Tellus's aggressive wooing are feminized; he behaves with her as she will with Corsites, admitting: 'With Tellus, fair Tellus, have I dissembled, using her but as a cloak for mine affections' (2.1.25-6).

36 For a more extensive discussion of the common repercussions for shrewish and disorderly wives, see Theodora Jankowski, Women in Power in Early Modern Drama (Urbana and Chicago, 1992), chapter 2, and Lisa Jardine, Still Harping on Daughters: Women and Drama in the Age of Shakespeare (New York, 1989), chapter 4.

37 Donald Edge also links the names of the maids to a line from Ovid's portrayal of Medea in Metamorphoses; see 'Lyly-Ovid Parallels: Endimion's Sources', Notes and Queries 31.2 (1984), 179); these disobedient, quarrelsome girls have a strong connection with the one who is both a headstrong girl and a murderous wife.

38 John Knox, The First Blast of the Trumpet against the Monstrous Regiment of Women (Amsterdam, 1972), C1.

39 Ibid, B3.

40 Ibid.

41 Diane Purkiss, 'Medea in the English Renaissance', Edith Hall, Fiona Macintosh, and Oliver Taplin (eds), Medea in Performance: 1500-2000 (Oxford, 2000), 33-6.

42 Ibid, 40.

43 See Roberts, 'Descendants of Circe', Jonathan Barry, Marianne Hester, and Gareth Roberts (eds), Witchcraft in Early Modern Europe: Studies in Culture and Belief (Cambridge, 1996), for the detailed history of this debate and for the role Circe played in the literature of renaissance.

44 John Lyly, Euphues: The Anatomy of Wit. Euphues \& His England, ed. Morris William Croll and Harry Clemons (New York, 1964), 445.

45 Stuart Clark, Thinking with Demons: The Idea of Witchcraft in Early Modern Europe (Oxford, 1997), 659.

46 Ibid, 666.

47 Ibid, 665.

48 John Aylmer, An Harborowe for Fauthfull and Trewe Subjects, against the late blowne Blaste, concerninge the Government of Women (Strasborowe, 1559), B3. 
49 Ibid.

50 For the history of the Roman goddess Diana and her role in presentation and selfrepresentation of monarchs, see Berry, Of Chastity and Power, chapter 2. Doran sees the use of Diana imagery as corresponding to the political needs of the later years of Elizabeth's reign; see Susan Doran, 'Virginity, Divinity and Power', Susan Doran and Thomas S. Freeman (eds), The Myth of Elizabeth (New York, 2003), 187-90.

51 Frances Yates offers a detailed discussion of this particular allegory in 'Queen Elizabeth I as Astraea', Astraea: The Imperial Theme in the Sixteenth Century (London, 1985), 29-87.

52 Louis Montrose, The Subject of Elizabeth: Authority, Gender, and Representation (Chicago and London, 2006), 1.

53 Andrew Belsey and Catherine Belsey, 'Icons of Divinity: Portraits of Elizabeth I', Lucy Gent and Nigel Llewellyn (eds), Renaissance Bodies: Human Figure in English Culture c. 1540-1660 (London, 1990), 25.

54 Belsey and Belsey suggest that, in this diagram, the queen is usurping the role of God, both in her position and in apparel ('Icons of Divinity', 27-8). See also 28-31 for similar portrayals of Elizabeth during her reign.

55 For analysis of some entertainments and tilts, see Berry, Of Chastity and Power, chapter 4; Susan Frye, Elizabeth I: The Competition for Representation (Oxford, 1993), chapter 2; and Helen Hackett, Virgin Mother, Maiden Queen: Elizabeth I and the Cult of the Virgin Mary (New York, 1995), 78-99. In arguing a connection between sixteenth-century presentations of Elizabeth and medieval presentations of the Virgin Mary, Hackett in particular points to an emphasis laid on the queen's thaumaturgical potential.

56 In his discussion of Lyly's allegories, Peter Saccio goes as far as to suggest that Cynthia, among other things, personifies Truth, one of the Four Daughters of God; see Saccio, The Court Comedies of John Lyly: A Study in Allegorical Dramaturgy (Princeton, 1969), 175-86.

57 See Sigrid Brauner, Fearless Wives and Frightened Shrews: The Construction of the Witch in Early Modern Germany, ed. Robert H. Brown (Amherst, 1995), especially chapter 4 .

58 Endymion, ed. Bevington, 147.35n.

59 Brian P. Levack, The Witch-Hunt in Early Modern Europe (London and New York, 1995), 146.

60 Berry, Of Chastity and Power, 111.

61 There is a certain disagreement among historians as to how close this is to Elizabeth's actual relationships with her ladies in waiting. As Brown argues in 'Companion Me with My Mistress', Susan Frye and Karen Robertson (eds), Maids and 
Mistresses, Cousins and Queens: Women's Alliances in Early Modern England (Oxford and New York, 1999), some of these relationships were quite warm and affectionate. On the other hand, Elizabeth did demand extraordinary obedience from her ladies in waiting and wished to control, among other things, their marital choices. Unlike Cynthia, who is eager to make as many matches as possible, Elizabeth was more likely to forbid marriages that her ladies wanted to make.

62 They are commanded to go to different countries, to speak to anyone or anything that might provide remedy. See 1.3.48-55.

63 Earlier in the act, Eumenides explains to the newly awakened Endymion that Semele cannot speak a word, since 'if she do she loseth her tongue' (5.1.171).

64 Gwynne Kennedy, Just Anger: Representing Women's Anger in Early Modern England, (Carbondale and Edwardsville, 2000), 3-4.

65 Jardine, Still Harping on Daughters, 173.

66 Lloyd E. Berry (ed.), John Stubb's Gaping Gulf with Letters and Other Relevant Documents (Charlottesville, 1968), 3.

67 See Ilona Bell, “'Sovereaigne Lord of lordly Lady of this land”: Elizabeth, Stubbs, and the Gaping Gulf', Julia M. Walker (ed.), Dissing Elizabeth: Negative Representations of Gloriana (Durham and London, 1998), for a more detailed discussion of Stubbs's phrasing. Bell argues that Elizabeth's great displeasure was caused precisely by Stubbs's paternalistic tone and his focus on the female body of the queen as a threat to the body politic.

68 'Appendix I: The Proclamation of the Queen', Lloyd E. Berry (ed.), John Stubb's Gaping Gulf with Letters and Other Relevant Documents (Charlottesville, 1968), 152.

69 See G.K. Hunter's discussion of the dates in John Lyly: The Humanist as Courtier (Cambridge, 1962), 356, n. 63. Lyly places Elizabeth's promises both in 1585 and 1588 in two different texts - a letter to Robert Cecil and a petition to the queen herself. Hunter concludes that 1585 is the probable date in this case, suggesting that she might have 'made a general promise at this date, and made it more specific at the later date'.

70 Ibid, 78.

71 Ibid, 80-1.

72 Qtd in ibid, 85.

73 Ibid, 86.

74 See Levin, The Heart and Stomach of a King, chapter 4, for a discussion of various rumours concerning Queen Elizabeth's private life.

75 Montrose outlines some of the post-1603 representations of Elizabeth in her last years in The Subject of Elizabeth, chapter 17. 
